Proc. Estonian Acad. Sci. Eng., 2006, 12, 1, 72-80

\title{
Trends in domestic hot water consumption in Estonian apartment buildings
}

\author{
Teet-Andrus Kõiv and Alvar Toode
}

Department of Environmental Engineering, Tallinn University of Technology, Ehitajate tee 5, 19086 Tallinn, Estonia; teet.koiv@ ttu.ee

Received 16 September 2005, in revised form 5 January 2006

\begin{abstract}
Domestic hot water consumption trends in Estonian apartment buildings during the last 30 years have been investigated. Measurement results show that the factual maximum consumption values are substantially less than the design values. For dimensioning instantaneous heat exchangers for domestic hot water heating a new load calculation formula is recommended.
\end{abstract}

Key words: apartment building, domestic hot water, consumption profile.

\section{INTRODUCTION}

In the 1970s the domestic hot water consumption in residential buildings was relatively high; for example, in the former Soviet Union 95 1/d per person or more $\left[{ }^{1,2}\right]$. The latest investigations tell us about a decrease in domestic hot water consumption: in Russia 68-92 1/d per person (as design values) $\left[{ }^{3}\right]$, in Finland about $85 \mathrm{l} / \mathrm{d}$ per person $\left[{ }^{4}\right]$ and in USA residential homes $46-85 \mathrm{l} / \mathrm{d}$ per person $\left[{ }^{5}\right]$. Changes in the consumption profile are different in different countries. There are only minimal changes in domestic hot water consumption profile in Russia [ $\left.{ }^{6}\right]$. Nowadays, domestic hot water consumption profile of apartment buildings in Estonia $\left[{ }^{7}\right]$ is close to consumption profiles in USA $\left[{ }^{8}\right]$ and Denmark $\left[{ }^{9}\right]$.

The share of heat consumption for water heating in Estonian apartment buildings in the general heat consumption has been about 20-40\% during the last 30 years. The larger numbers belong to the 1970s. The total heat consumption in apartment buildings has changed from 350 in the $1970 \mathrm{~s}$ to $200 \mathrm{kWh} / \mathrm{m}^{2}$ per year in 2004. 
The first investigation of domestic hot water consumption in the 1990s was carried out in Tallinn in $1998\left[^{10}\right]$. The first more extensive analysis of domestic hot water consumption by the authors of the paper was made in 2000 on the basis of the 1999 consumption data $\left[{ }^{11}\right]$. The latest one was made in $2005\left[{ }^{7}\right]$.

\section{CHANGES IN DOMESTIC HOT WATER CONSUMPTION}

The domestic hot water consumption dynamics in apartment buildings from 1999 to 2004 is shown in Table 1. We can see a considerable decrease in consumption. In small cities of Estonia the domestic hot water consumption is about $15 \%$ less.

Comparison of the weekly consumption data in 1974 and 2005 is shown in Fig. 1. From 1974 to 2005 the domestic hot water consumption in apartment buildings has decreased more than three times.

Table 1. Domestic hot water consumption $1 /\left(\mathrm{m}^{2} \cdot \mathrm{d}\right)$ in investigated apartment buildings from 1999 to 2004

\begin{tabular}{l|c|c|c|c|c|c}
\hline Consumption & 1999 & 2000 & 2001 & 2002 & 2003 & 2004 \\
\hline Average & 2.8 & 2.6 & 2.3 & 2.2 & 2.1 & $2.0^{*}$ \\
Range & $1.6-3.6$ & $2.1-3.3$ & $1.8-3.1$ & $1.7-2.8$ & $1.6-2.6$ & $1.7-2.7$
\end{tabular}

* 44 1/d per person.

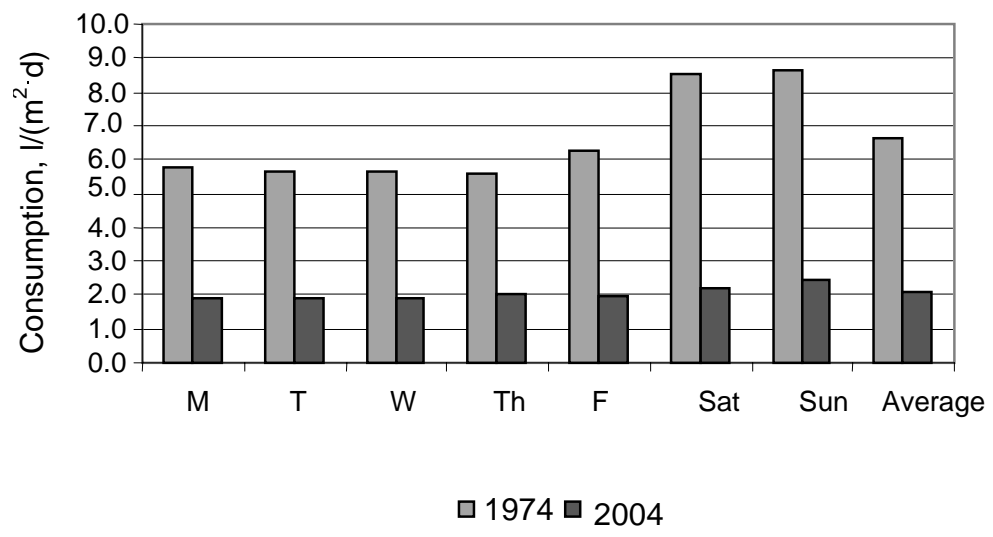

Fig. 1. Domestic hot water consumption on weekdays and on average in 1974 and 2004; the area is the general area of apartments. 


\section{DOMESTIC HOT WATER CONSUMPTION PROFILE}

Maximum domestic hot water consumption and consumption profile in apartment buildings were investigated in 1974 (using an experimental data logging system) and in 2005 using impulse water meters (one impulse per one litre), which were connected with data loggers; the measurement schema is shown in Fig. 2. The water consumption data collection of different apartment buildings was made during a week.

During 30 years considerable changes in people's lifestyle have taken place. To prove it, daily consumption profiles of two apartment buildings in 1974 and 2005 are shown in Figs. 3 and 4.

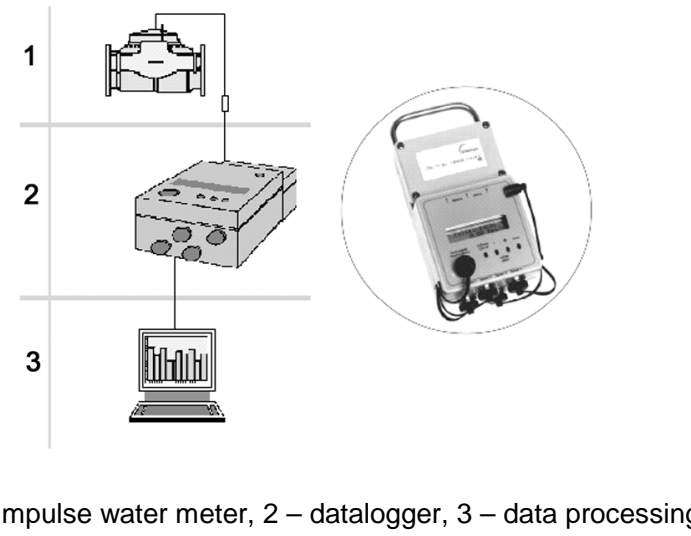

Fig. 2. Data measurement and processing system.

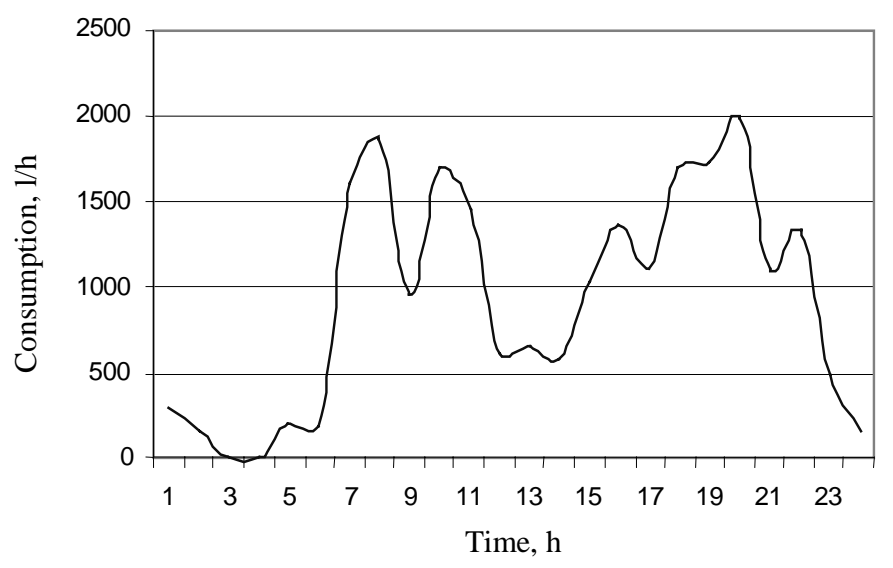

Fig. 3. Consumption profile of a 90-apartment building in 1974 (on Monday). 


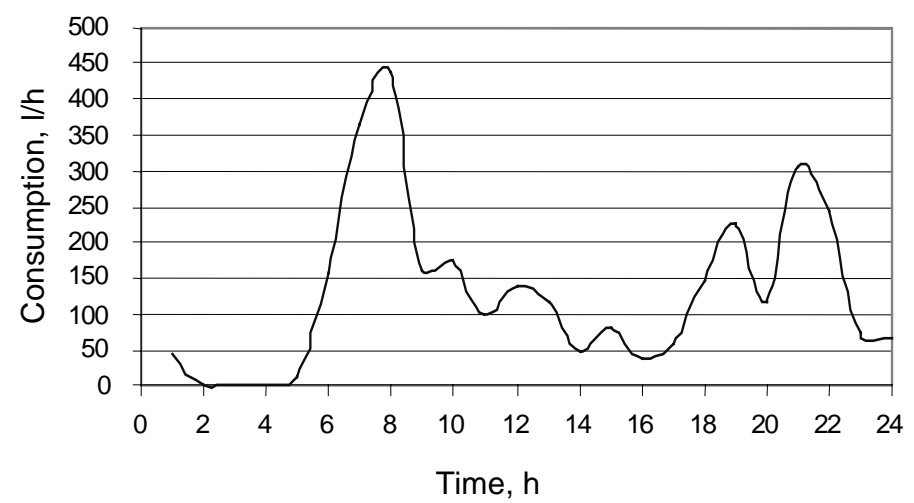

Fig. 4. Consumption profile of a 30-apartment building in 2005 (on Tuesday).

The maximum hourly variation in domestic hot water consumption is characterized by the ratio $k_{\mathrm{h}}$ of the maximum hourly consumption to the average hourly consumption of a week, which is calculated as:

$$
k_{\mathrm{h}}=\frac{G_{\mathrm{h}}^{\max }}{G_{\mathrm{h}}^{\text {avg }}},
$$

where $G_{\mathrm{h}}^{\max }$ is the maximum and $G_{\mathrm{h}}^{\text {avg }}$ is the average hourly domestic hot water consumption of the week.

The dependence of $k_{\mathrm{h}}$ on the number of apartments in a building is shown in Fig. 5.

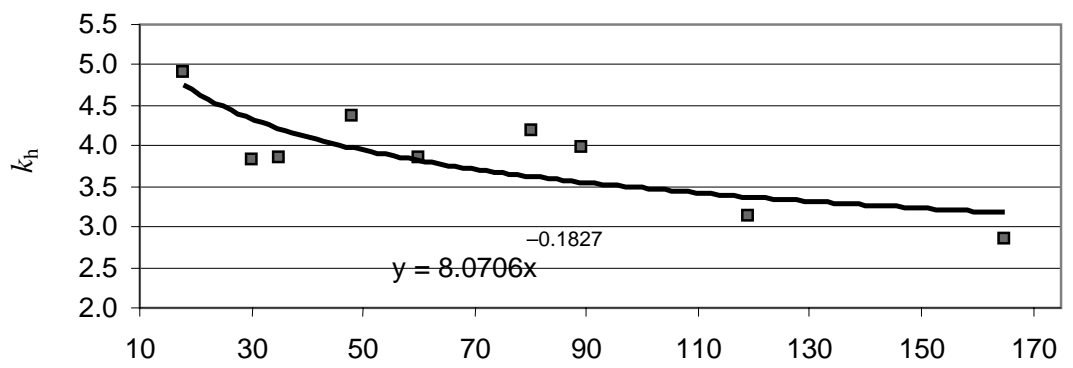

Number of apartments

Fig. 5. The dependence of $k_{\mathrm{h}}$ on the number of apartments in the building. 
In recent years great changes in the relative domestic hot water consumption during the weekend have taken place. The increase in the consumption during the weekend is not so considerable any more. In comparison with the water consumption on workdays the rise in the weekend consumption in 1974 was 1.5 times while now it is only 1.2 times. At present the daily consumption is characterized by the morning maximum (Fig. 4) and it is more close to the consumption profiles in the West European countries $\left[{ }^{9}\right]$ and USA $\left[{ }^{8}\right]$.

\section{MAXIMUM CONSUMPTION AND A NEW LOAD CALCULATION FORMULA}

The maximum domestic hot water consumption has decreased and is considerably lower than that calculated using $\left[{ }^{12}\right]$ (Fig. 6).

Calculation of the domestic hot water design flow rate in residential buildings is based on the sum of nominal flows of standard type of water outlets. Calculation is made using a graph, table or formula

$$
q_{\mathrm{dh}}=q_{\mathrm{N}}+\Theta\left(Q-q_{\mathrm{N}}\right)+A \sqrt{q_{\mathrm{m}} \cdot \Theta} \sqrt{Q-q_{\mathrm{N}}},
$$

where $q_{\mathrm{dh}}$ is the design flow rate of the domestic hot water $(1 / \mathrm{s}), q_{\mathrm{N}}$ is the maximum flow rate of domestic hot water for water outlets $(1 / \mathrm{s}), q_{\mathrm{m}}$ is the weighted mean flow rate of domestic hot water for water outlets $(0.21 / \mathrm{s}), Q$ is the sum of the nominal flow rates of domestic hot water for water outlets (nominal flow rates are $0.2 \mathrm{l} / \mathrm{s}$ for shower, $0.3 \mathrm{l} / \mathrm{s}$ for bath tube and $0.2 \mathrm{l} / \mathrm{s}$ for kitchen sink), $A$ and $\theta$ are constants depending on the desired safety against overloading (for residential buildings $A=3.1$ and $\theta=0.015$ ).

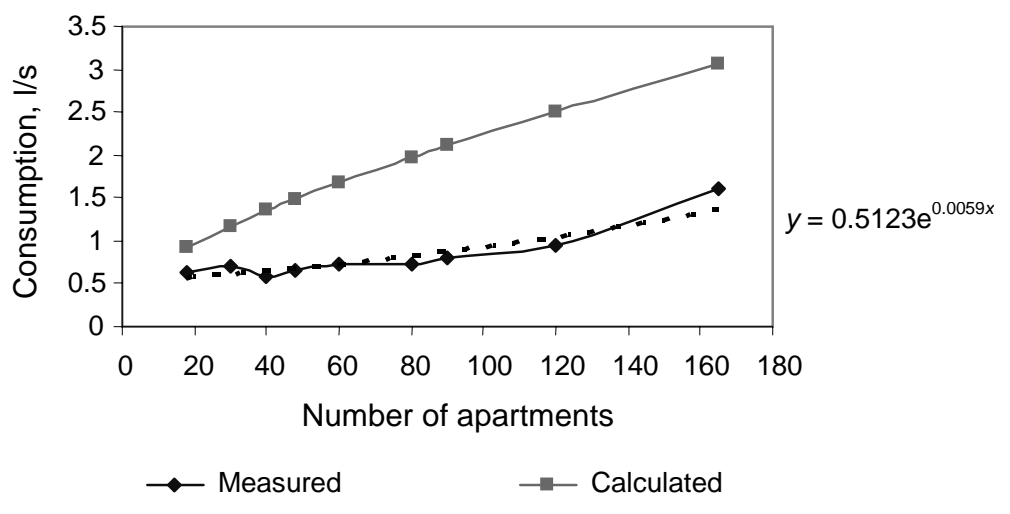

Fig. 6. Measured and calculated (on the basis of EVS $\left[{ }^{12}\right]$ ) values of maximum domestic hot water consumption in different apartment buildings in 2005. 
For calculating the domestic hot water load $\Phi$ for dimensioning instantaneous heat exchangers, the following formula was derived:

$$
\Phi=B(30+15 \sqrt{2 n}+0.2 n),
$$

where $n$ is the number of apartments, $B$ is a coefficient that takes into account the domestic hot water temperature $(B=1.0$ if hot water design temperature is $55^{\circ} \mathrm{C}, B=1.1$, if this temperature is $60^{\circ} \mathrm{C}$ and $B=1.2$, if this temperature is $65^{\circ} \mathrm{C}$ ). Equation (3) is valid for apartments with one bathroom and a kitchen.

Figure 7 shows domestic hot water heating load values for dimensioning instantaneous heat exchangers in different apartment buildings on the basis of Eq. (3).

Figure 8 presents domestic hot water heating load design values calculated by formula (3), by the Estonian Standard EVS 835:2003 (identical with D1 - the Finnish Construction Code), by SDHA (the Swedish District Heating Association) method and by SNiP 2.04.01-85 (the Soviet Construction Code). Calculation formulas are presented in the article Kõiv and Toode (2001) $\left[{ }^{3}\right]$. In Fig. 8 we can see that the results calculated by formula (3) are closer to the SDHA method, the reason being a very close number of residents in apartments.

Figure 9 shows design loads, calculated by formula (3), by the EVS/D1 method and by the measured values in 2005 . We can see that for large apartment buildings EVS and D1 give about twice higher loads.

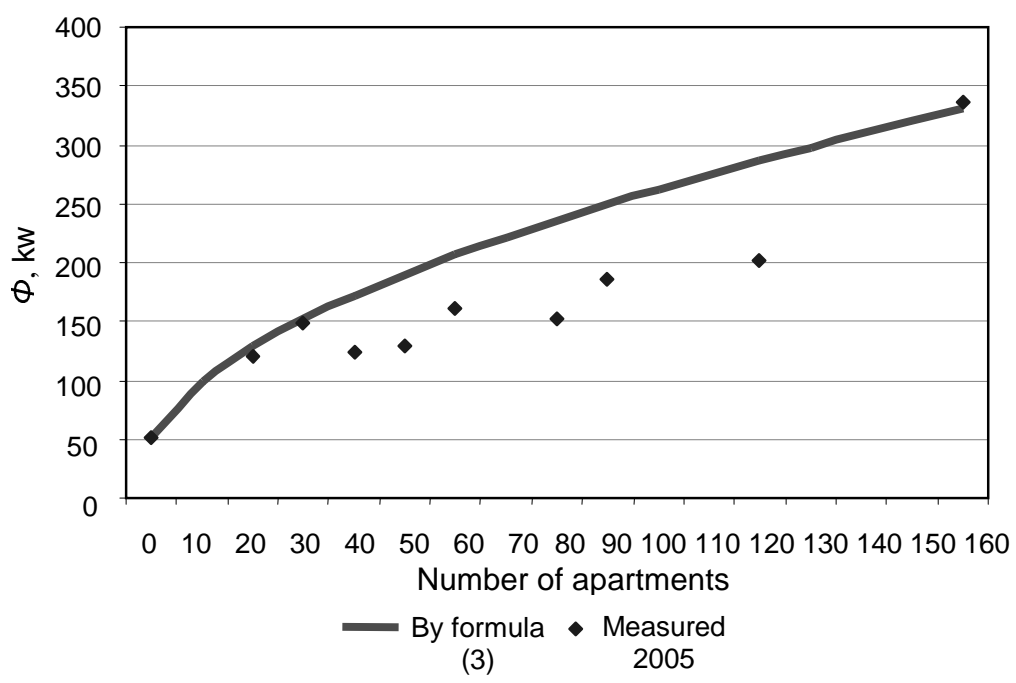

Fig. 7. Domestic hot water heating load values for dimensioning instantaneous heat exchangers in different apartment buildings, calculated using Eq. (3), and values calculated on the basis of measured domestic hot water consumption values. 


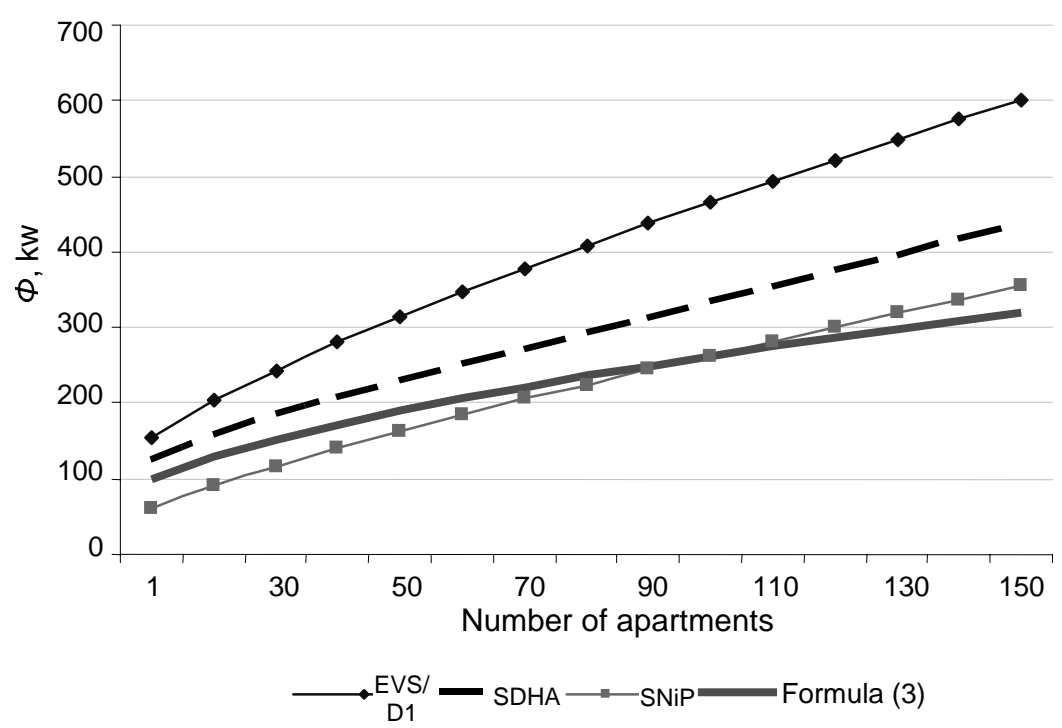

Fig. 8. Domestic hot water heating load design values calculated by different methods: EVS Estonian Standard EVS 835:2003; D1 - Finnish Construction Code; SDHA - Swedish District Heating Association; SNiP - Soviet Construction Code SNiP 2.04.01-85.

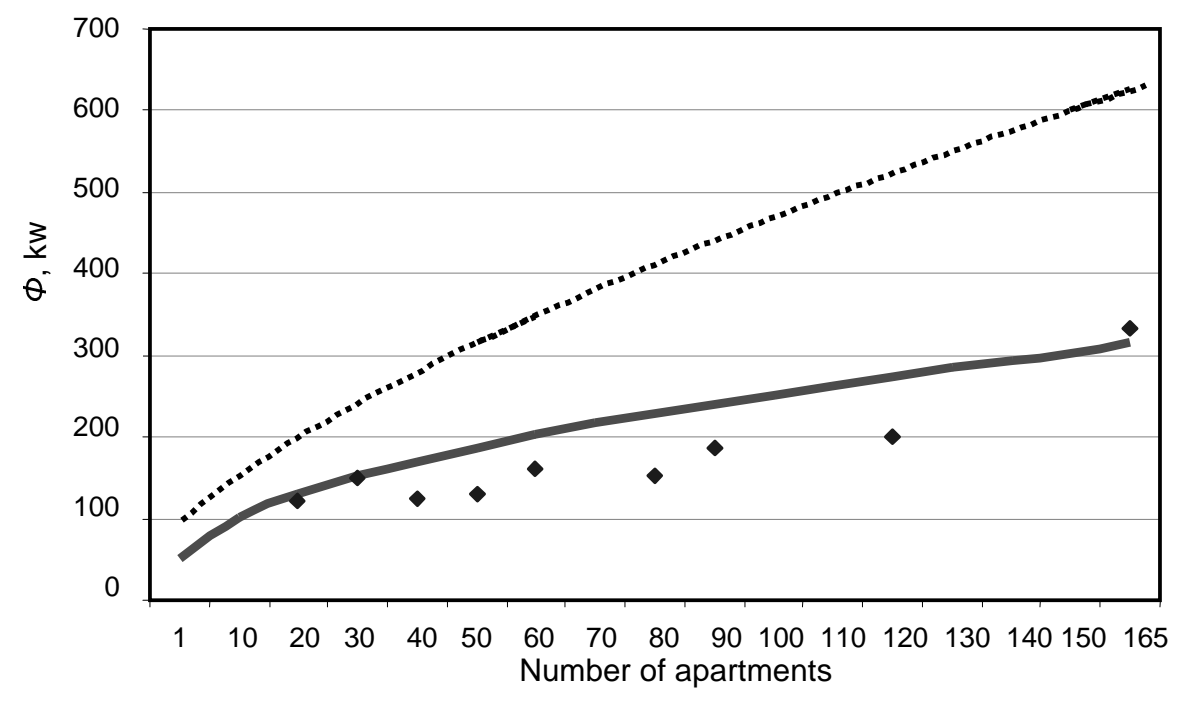

By formula (3) $\bullet$ Measured $2005 \quad \ldots \ldots$ EVS/D1

Fig. 9. Comparison of domestic hot water heating loads calculated by formula (3), by the EVS/D1 method and on the basis of measured values. 


\section{CONCLUSIONS}

In the last 30 years great changes in domestic hot water consumption in apartment buildings have taken place (Fig. 1). The main reasons for the decrease in domestic hot water consumption are:

- consumption metering in apartments and payment for real consumption;

- increasing cost of water and heat;

- extensive renovation of domestic hot water systems, including renovation of the circulation;

- use of modern water saving equipment (taps, showers).

At the same time there have been considerable changes in maximum water consumption. Following that a new methods for dimensioning instantaneous heat exchangers in apartment buildings is recommended. This improves the control of domestic hot water temperature, especially in conditions of low external temperature, and decreases expenses on the equipment.

\section{ACKNOWLEDGEMENT}

The authors are grateful to the Ministry of Economy and Communication for supporting the investigation.

\section{REFERENCES}

1. Borodkin, J. D. and Dvoretskov, N. G. Profile of domestic hot water consumption in residential buildings and influence of the control of heat supply. "Teplosnabzhenie gorodov", Nautshnye trudy AKH imeni K. D. Pamfilova, 1973, No. 95, 49-52 (in Russian).

2. Kõiv, T.-A. Experimental research of domestic hot water consumption profiles by residents in Tallinn. Proc. TPI, 1977, No. 420, 35-42 (in Russian).

3. Pukhkal, V. Selection of equipment for measuring the volume and flow rate of water in domestic hot water systems. Inzhenernye sistemy (AVOK Severo-Zapad), 2002, No. 2(6), 44-45 (in Russian).

4. Seppänen, O. Rakennusten lämmitys. Gummerus OY, Jyväskyla, 2001.

5. Domestic Hot Water System Modeling for the Design of Energy Efficient Systems. NAHB Research Center, USA, 2002. www.nahbrc.org

6. Pukhkal, V. Calculation of domestic hot water consumption in existing residential buildings. Inzhenernye sistemy (AVOK Severo-Zapad), 2003, No. 2(10), 26-29 (in Russian).

7. Toode, A. and Kõiv, T.-A. Domestic hot water consumption investigation in apartment buildings. Proc. Estonian Acad. Sci. Eng., 2005, 11, 207-214.

8. Fairey, P. and Parke, D. A Review of Hot Water Draw Profiles Used in Performance Analysis of Residential Domestic Hot Water Systems. 2004. www.fsec.ucf.edu

9. Sonne, P. Peak shaving. News from Danish Board of District Heating. 1994, No. 1.

10. Kõiv, T.-A. Heat energy consumption in heating and hot tap water systems in apartment buildings. Proc. Estonian Acad. Sci. Eng., 1998, 4, 225-232.

11. Kõiv, T.-A. and Toode, A. Heat energy and water consumption in apartment buildings. Proc. Estonian Acad. Sci. Eng., 2001, 7, 235-241.

12. Kinnistu veevärgi projekteerimine. EVS 835:2003. Eesti Standardikeskus, Tallinn, 2003. 


\title{
Muutustest Eesti kortermajade sooja vee tarbimises
}

\author{
Teet-Andrus Kõiv ja Alvar Toode
}

Sooja vee tarbimine ja selle ebaühtlus sõltuvad elanike harjumustest ja seda mõjutavad maksustamine, kasutatavad seadmed ja süsteemi seisukord. Artiklis on esile on toodud väga suured muutused sooja vee tarbimises ja tarbimisrežiimis viimasel paarikümnel aastal Eestis. Ajavahemikus 1974 kuni 2004 vähenes sooja vee tarbimine üle kolme korra. Uurimistulemused näitavad, et sooja vee tarbimise tegelikud maksimumväärtused on kuni kaks korda väiksemad arvutuslikest. Sellest tulenevalt on esitatud uus valem sooja tarbevee soojendamiskoormuse määramiseks kiirveesoojendite dimensioneerimisel. 